\title{
Civilization Under Construction: Depictions of Architecture on the Column of Trajan
}

\author{
ELIZABETH WOLFRAM THILL
}

\begin{abstract}
More than 300 depictions of architectural structures appear throughout the Column of Trajan, illustrating both Roman and Dacian fortifications and settlements. Despite the prevalence of architectural depictions on the column, there has been little attention specifically devoted to these important components of the frieze. While recent scholarship has focused on the composition and message of the column as a whole, for the most part this work has not contributed to the interpretation of architecture on the frieze. Previous discussions of the architectural representations have focused almost exclusively on reconciling the pictorial record with the archaeological record and on explaining away what has been seen as a series of mistakes in the architecture on the frieze. This article demonstrates that the many features traditionally interpreted as misunderstandings actually form consistent patterns that draw a purposeful contrast between a supposedly superior Roman culture and a primitive, barbarian Dacian culture.*
\end{abstract}

\section{INTRODUCTION}

This article presents select results of a comprehensive statistical and qualitative analysis of all architectural structures on the Column of Trajan frieze. It focuses on depictions of military architecture as a case study for the relationship between actual architecture and symbolic representation on the frieze. Rather than specifically addressing the problem of who was respon-

\footnotetext{
* This article is derived from my master's thesis, written at the University of North Carolina at Chapel Hill. Sheila Dillon and Nicola Terrenato gave much helpful advice as thesis committee members, for which I am very grateful. I would like to extend special thanks to my committee chair Monika Truemper, who has been an unfailing source of detailed reviews, advice, and enthusiasm throughout all stages of my thesis and this article. Thank you also to the editors and anonymous reviewers of the AJA for their invaluable comments. Any mistakes that remain are of course my own. I am very grateful to Antonio Di Tanna and the Museo della Civiltà Romana for permission to use my photos of their casts in this article. I would also like to thank my family and everyone in the Department of Classics at the University of North Carolina at Chapel Hill for their tireless enthusiasm and support over many years. In this article, I follow the scene divisions and numbering system established by Cichorius $(1896,1900)$, the traditional reference system for the Column of Trajan frieze. A catalogue covering select architectural structures on the frieze of the Column of Trajan is available on the AJA Web site
}

sible for the inclusion of the architectural depictions, ${ }^{1}$ this article employs the term "the production team" in a purposefully neutral sense to refer collectively to anyone and everyone involved in the design of the reliefs, including possibly (but not necessarily) the imperial entourage. The problem of visibility is not addressed, ${ }^{2}$ except to note that many of the depictions examined are difficult to see from ground level. Nevertheless, the details of the architectural depictions should be treated as significant features of the frieze, regardless of their visibility, with the potential to play a role in conveying the intended message of the column.

\section{PREVIOUS RESEARCH AND A NEW APPROACH TO THE ARCHITECTURAL DEPICTIONS}

Early scholarship on the Column of Trajan tended to focus on the column as a historical narrative, with the frieze serving as a substitute for lost textual accounts of the Dacian Wars. Recent work has moved away from such literal interpretations of the frieze, and scholars such as Hölscher and Settis have stressed the artistic and thematic considerations affecting the composition and design of the monument. ${ }^{3}$ Research on the architectural depictions on the frieze, however, has been generally unaffected by this recent shift in focus, and discussions of the architecture have remained

(http://www.ajaonline.org), under "Supplemental Data."

${ }^{1}$ For a summary and discussion of the debate over the authorship and artistic forces behind the Column of Trajan, see Galinier 2007, 8-30; see also Richmond 1982, 3; Coulston 1988, 96; 1990b, 303; Lepper and Frere 1988, 16-17, 23, 2730, 158; Settis 1988, 100-2; Coarelli 2000, 30-1; Hölscher 2002, 127-28; Packer 2008, 471-72. Rockwell (1985, 101-5) has suggested that the backgrounds of the frieze, including all architecture, were executed separately from the figures. This argument, however, seems to rely primarily on selected instances in which the background does not accord well with the actions of the figures.

${ }^{2}$ For extensive discussion of problems (both logistical and conceptual) for the visibility of the frieze, see Galinier 2007, 134-63; see also Coulston 1988, 13-14, 107-8, 111; 1990b, 302; Hölscher 1991a, 262; 2002, 139-40; Claridge 1993, 22; 1998, 167; Packer 1997, 113; Coarelli 2000, 19-21; Zanker 2000a, vii; Clarke 2003, 35; Settis 2005, 65, 68-70; Dillon 2006, 259.

${ }^{3}$ Hölscher 1991a, 1991b, 2002; Settis 1988, 2005; but see Lehmann 1926. 
primarily descriptive, with an eye to reconstructing the narrative and physical world of the Dacian Wars. ${ }^{4}$

This study presents a fundamentally different approach to the architectural depictions. Rather than focusing on the debated identification of various individual depictions, it presents the results of a comprehensive analysis of all depicted architecture on the column. The starting point for this study was the compilation of a catalogue covering each architectural structure on the frieze. ${ }^{5}$ The aim was to discern whether broad quantitative and qualitative trends could be detected for the architectural depictions, and whether these trends could be related to thematic concerns for the Column of Trajan as a whole.

Several aspects of each architectural structure were noted in its catalogue entry, including its apparent cultural association, construction material, notable structural features, spatial relationship to other structures, compositional rendering, and narrative setting. The most crucial classificatory distinction for the analysis was that of cultural association. Each architectural structure was classified as "Roman," "Dacian," or "unclear," depending on what cultural influences were apparently dominant for the structure. For a classification of "Roman," the structure needed to be (1) a clearly Roman architectural type (e.g., an amphitheater), (2) part of an urban landscape incorporating buildings of clearly Roman architectural types, or (3) associated with the Roman army (e.g., camps under construction and/or occupied by legionaries). A parallel classificatory scheme was employed to distinguish "Dacian" architectural structures. For an architectural structure to be classified as "Dacian," it needed to (1) have an unfamiliar, clearly non-Roman architectural type (e.g., built on stilts); (2) be part of an urban landscape incorporating buildings of clearly non-Roman architectural types; or (3) be associated with the Dacian populace through narrative (e.g., structures under explicit Dacian occupation). An attempt was made

\footnotetext{
${ }^{4}$ Discussions of the frieze as a whole (Lehmann 1926; Richmond 1982; Lepper and Frere 1988; Koeppel 1991, 1992; Coarelli 2000; Depeyrot 2007) tend to mention the architecture on the frieze in passing, generally limiting their discussions to brief descriptions of the structures. Turcan-Déléani (1958) and Coulston (1990a) have written more specific evaluations of the civilian architecture and military fortifications, respectively, but neither author is chiefly concerned with situating the architectural depictions within the thematic concerns of the column as a whole. Turcan-Déléani primarily approaches the depictions from a compositional perspective, and focuses in particular on how the composition relates to the historicity of the architectural landscapes depicted on the frieze. Coulston's article focuses on the classification and structural analysis of the various fortifications. For studies of architectural depictions in Roman state relief in general, see
}

always to err on the side of ambiguity to avoid spurious classifications. Those structures whose associations were ambiguous were classified as "unclear."

The classification according to construction material was relatively straightforward. For a structure to be classified as "stone," it needed to have either block hatching or select features-such as arched openings-possible only in stone construction. A classification of "wood" was dependent on the clear indication of either planking or peg construction for the structure's walls. There was a small number of structures that exhibited features of both types of construction; these were classified as "combination." If the construction method was ambiguous, a structure was classified as "unclear." Specific features noted for each include doorways, windows, roofs, roundels, and merlons.

I summarize here several interesting and important quantitative trends in the depicted architecture of the frieze. As compiled in the catalogue, the Column of Trajan frieze features 326 architectural structures. Most of these structures can be directly associated with either Roman or Dacian cultural influence, according to the methodology outlined above. Seventy percent of all structures on the frieze fall within the category of Roman architecture, while $27 \%$ of all structures can be associated specifically with Dacian culture. There is, in other words, significantly more Roman than Dacian architecture on the frieze.

Roman and Dacian architectural structures show interesting divergence in their depicted construction techniques (table 1). Nearly $70 \%$ of all architectural structures associated with Roman culture are specifically depicted as stone-built, featuring some combination of rectangular hatching, arches, or other structural features possible only in stone or concrete. Only $25 \%$ of all Dacian structures share these same features. Conversely, $56 \%$ of all Dacian architectural structures, but only $16 \%$ of all Roman structures, are depicted as made of wood, with planking and/or pegs

\footnotetext{
Maier 1985; Grunow 2002; Quante-Schöttler 2002.

${ }^{5}$ I compiled this catalogue during research for my master's thesis. All numbers, percentages, typologies, and classifications within the current article refer back to this catalogue. An abbreviated version can be found on the AJA Web site (http:// www.ajaonline.org), under "Supplemental Data." The main pictorial sources for the catalogue were Coarelli's (2000) edition of photographs of the frieze and my own photographs of the column casts in the Museo della Civiltà Romana. All the images presented here are taken from these photographs of the casts, with many thanks extended to the museum for permission to publish them. In my analysis, my photographs were crucial in picking out and clarifying details in the architecture, since many details are difficult to see in reproductions of entire scenes.
} 
Table 1. Construction Materials for Roman and Dacian Architectural Structures on the Column of Trajan.

\begin{tabular}{lcc}
\hline Construction Material & Roman $(\mathrm{n}=225)$ & Dacian $(\mathrm{n}=88)$ \\
\hline Stone only & $154(68.4 \%)$ & $22(25.0 \%)$ \\
Wood only & $36(16.0 \%)$ & $49(55.7 \%)$ \\
Combination & $2(0.9 \%)$ & $4(4.5 \%)$ \\
Unclear & $33(14.7 \%)$ & $13(14.8 \%)$ \\
\hline
\end{tabular}

clearly represented. This distinction, between predominantly stone construction for Roman architecture and predominantly wooden construction for Dacian structures, draws a purposeful contrast between the two cultures by portraying Roman architecture as sophisticated and permanent and Dacian architecture as primitive and ephemeral.

\section{ARCHITECTURE AND THE ROMAN ARMY}

The predominance of stone construction for Roman architecture is clear in the depictions of Roman military fortifications. Scholars have long noted the important role played on the frieze by the military architecture in highlighting the technical expertise of the Roman army. ${ }^{6}$ Modern interest in the particulars of the military architecture, however, has been primarily concerned with the accuracy in the depictions, since these images are often the only known representations of activities and structural features that leave little trace in the archaeological record. ${ }^{7}$

For all Roman fortifications on the frieze, walls are depicted with rows of regular, horizontal rectangular blocks, with alternating joints between the rows (fig. 1). This is exactly the same technique used for the surrounding walls and interior buildings of the civilian settlements, often in conjunction with large arched gateways, colonnades, and other features of stone architecture (fig. 2). Richmond, however, famously argued that in the case of Roman military fortifications,

\footnotetext{
${ }^{6}$ Richmond 1982, 3-5; Coulston 1988, 39; Williams 1998, 175; Hölscher 2002, 137.

${ }^{7}$ Johnson 1983, 56-7, 63, 86, 99; McCarthy 1986, 340; Coulston 1988, 22, 24-5; Lepper and Frere 1988, 264; Williams 1998, 175. Reconstructions of frontier forts, in particular, have relied on the Column of Trajan for their upper structures and overall appearance (Johnson 1983, 56-7, 86; Coulston 1990a, 39, 46). For the dangers of such practice, see Coulston 1988, 138-39, 142; 1990a, 41.

${ }^{8}$ Richmond 1982, esp. 5, 21-2; Lepper and Frere 1988, 62. For the same issue regarding the Column of Marcus Aurelius, see Hanoune 2000, 208, 210.

${ }^{9}$ E.g., Johnson 1983, 63-4; Lepper and Frere 1988, 62-3, 264. While Coulston (1990a, 39-40, 44, 46) questions Rich-
}

the rectangular hatching is in fact meant to represent the turf blocks of turf-and-timber construction. ${ }^{8}$ This argument has found a strong and influential following in subsequent scholarship. ${ }^{9}$

Richmond's arguments rely on a firm belief that the military fortifications of the frieze were intended to accurately reflect genuine architectural practice. ${ }^{10}$ This belief led Richmond and others to assume that any deviation from realistic depiction on the frieze was a product of a misunderstanding between the draftsmen and sculptors. ${ }^{11}$ The depictions on the column, however, simply do not match architectural or archaeological reality in any coherent way. ${ }^{12}$ Attempts to explain away the inconsistencies through speculations of "who was familiar with what construction technique when" only lead to more confusion and contradictions. The assumption regarding the production team's intent thus appears to be inherently flawed. It is significantly easier to see the depictions of Roman military architecture as an effort to draw a positive contrast between Roman culture and barbaric Dacia. In this light, the representation of all Roman fortifications as stone takes on intriguing symbolic importance.

\section{Evaluation of the Turf-and-Timber Theory}

Richmond's arguments for interpreting the Roman fortifications as turf-and-timber constructions are based in large part on the logistical nonsense of constructing temporary military encampments out of ashlar

mond's interpretation of the specific actions of the construction scenes and the structural significance of the roundels, he nevertheless seems to follow Richmond in accepting that the roundels were meant to indicate turf-and-timber construction.

${ }^{10}$ Richmond 1982, 3-5; see also Coulston 1988, 136; Lepper and Frere 1988, 3. This is not to say that Richmond believed the frieze to be infallible; in fact, he generally questions the general historical reliability of its depictions (Richmond 1982, 4).

${ }^{11}$ Richmond 1982, 5-6.

${ }^{12}$ For a comprehensive list of inconsistencies and logical impossibilities in the depictions of military architecture, see Coulston 1988, 138-39. 


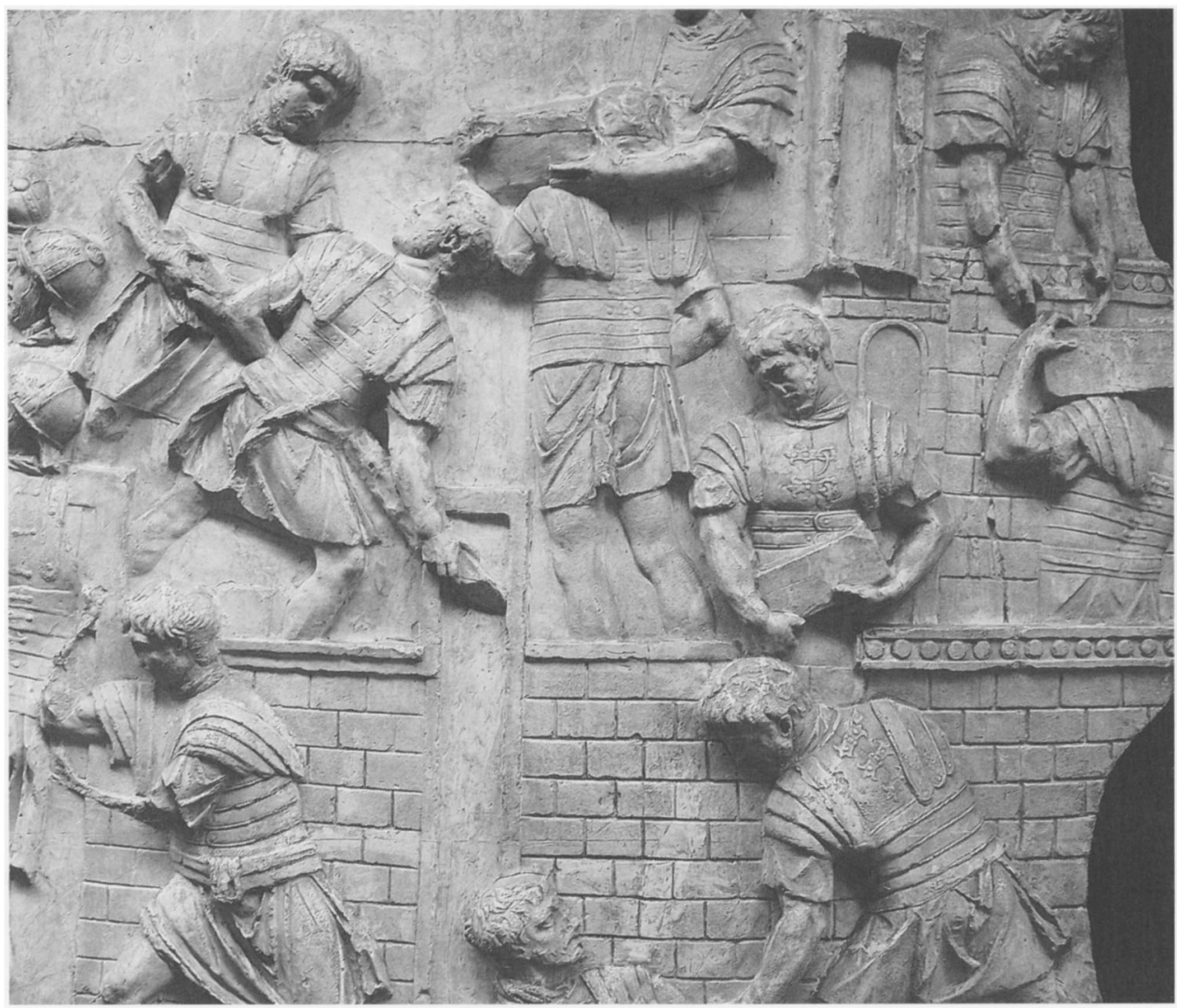

Fig. 1. Scene XI, construction of Roman military fortifications (courtesy Museo della Civiltà Romana, Rome).

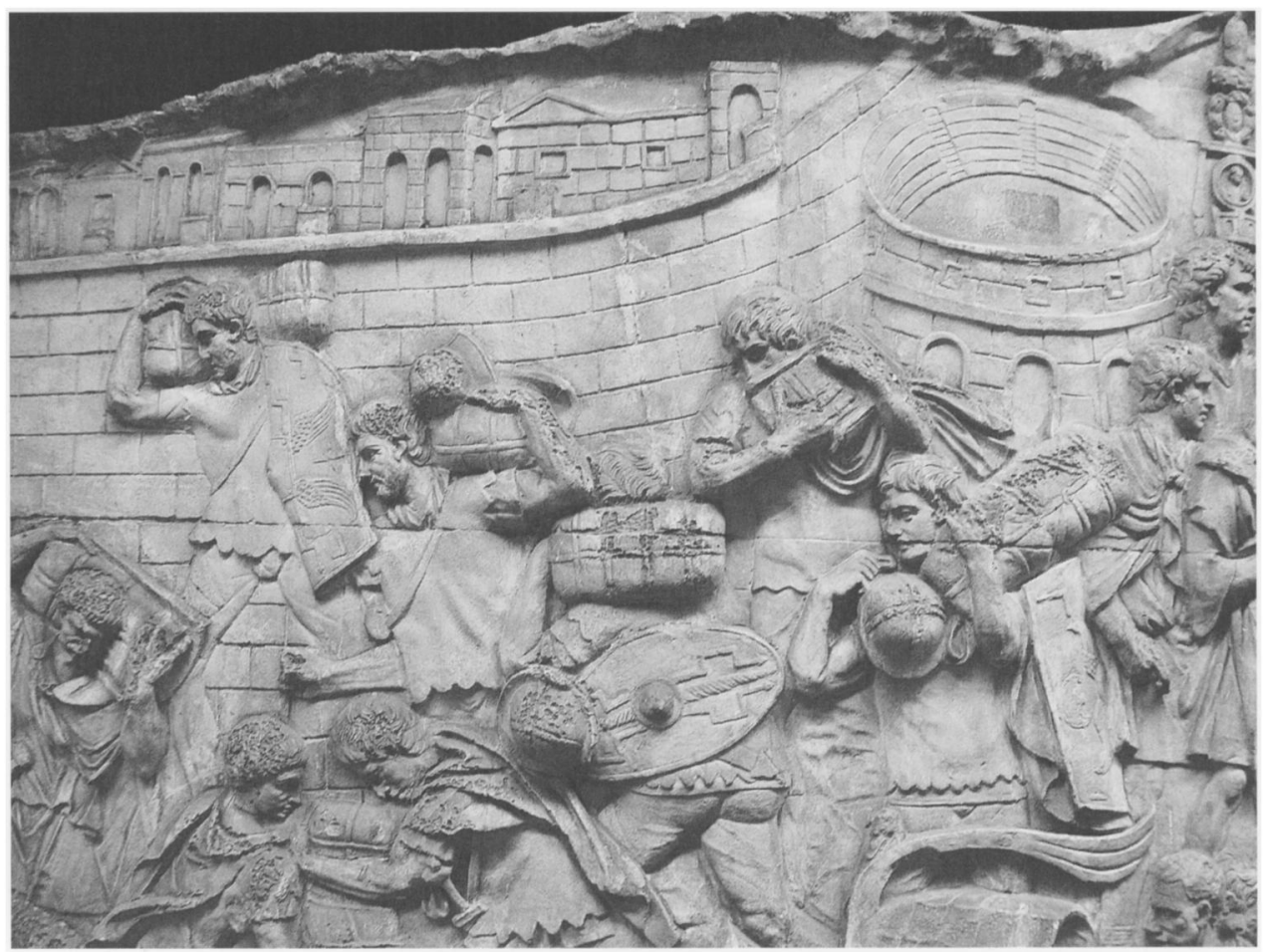

Fig. 2. Scene XXXIII, civilian settlement (courtesy Museo della Civiltà Romana, Rome). 
masonry. ${ }^{13}$ Turf proponents have also pointed out that permanent stone Roman fortifications are not attested for the Dacian frontier until the Hadrianic period or later. ${ }^{14}$ Such logistical and historical arguments, however, derive most of their strength from the assumption that the frieze is limited to purely realistic depictions of the Trajanic Dacian frontier.

More specific arguments for turf relate to the manner in which the Roman legionaries go about the process of construction. ${ }^{15}$ In particular, Scene XX has been argued to depict legionaries cutting turf blocks (fig. 3). ${ }^{16}$ It is unclear in any scene of digging soldiers (Scenes XI, XII, XX, XXXIX, LII, LVI, LX, LXV), however, exactly what they are doing. They could equally well be digging the ditches that were so crucial to the design of temporary Roman encampments. ${ }^{17}$ On the frieze, baskets often indicate digging, ${ }^{18}$ but in several scenes (Scenes XX, LII, LVI), whatever is in the baskets is clearly not turfs. Since one must cut turf in situ, not shape it like bricks after excavation, ${ }^{19}$ it seems more logical, if one takes these scenes literally, to interpret the digging as related to defensive ditches. So if Scene XX does in fact show the removal of turf, it should be taken as an isolated depiction, not a general theme of the frieze.

Coulston has argued convincingly that on the frieze in general, "individual blocks are treated as if they were made of stone," not turf. ${ }^{20}$ Stoneworking tools, for example, appear in several scenes (e.g., Scenes XXXIX, LX). ${ }^{21}$ In Scene XI, a soldier inserts a block immediately next to a line of supposedly timber roundels (see fig. 1), further spoiling the illusion that the logistics of turf-and-timber construction are faithfully

${ }^{13}$ Richmond 1982, 21; Coulston 1988, 137, 146; 1990a, 39, 44; Lepper and Frere 1988, 66, 145. It should be pointed out that constructing any significant fortification along the lines of those depicted on the frieze would require more work and material than logistically possible on campaign, regardless of construction method. The rampart at Carlisle, for example, is estimated to have required about $2,200 \mathrm{~m}^{3}$ of timber and more than 12 acres of turf (McCarthy 1986, 341). Even if one considers Carlisle to be significantly larger than any camp implied on the column, one must still question whether the scale of construction depicted on the frieze can be considered consistentin any building material-with the speed of campaigning.

${ }^{14}$ Richmond 1982, 22; Coulston 1988, 146, 149; 1990a, 44. For the question of earthwork or stone Roman forts for Dacia in this period, see, e.g., Gudea 1979, 77-82, 85; Cătăniciu 1981, 11-42; Lander 1984, 43-6, 61; Wilkes 2005, 155.

${ }^{15}$ Richmond 1982, 24; Lepper and Frere 1988, 103.

${ }^{16}$ Richmond 1982, 21-2; Coulston 1988, 144; 1990a, 42; Lepper and Frere 1988, 66. Although Richmond $(1982,24)$, followed by Johnson (1983, 59-60) and Lepper and Frere (1988, 103), chose Scene LX as the illustrative example of turf cutting, Scene XX, in my opinion, comes closest to definitive evidence for a depiction of turf cutting on the frieze, since it is the only scene that includes (possible) cut turfs on and in the ground. depicted. Lehmann, furthermore, argued that the construction scenes rely heavily on a few stock figure poses with parallels elsewhere in Roman art,${ }^{22}$ decreasing the likelihood that every movement represented has some significance specific to the construction technique at hand. ${ }^{23}$

The most famous argument for turf-and-timber construction is Richmond's interpretation of the lines of roundels along camp and fortification walls as the ends of wooden catwalks crowning earthen ramparts. ${ }^{24}$ Since such features are considered incompatible with stone construction, ${ }^{25}$ Richmond concluded that it was turf-and-timber, not stone, that the production team was seeking to portray for most military structures. ${ }^{26}$ The handling of these roundels on the frieze is hardly consistent, however, raising serious questions about the validity of roundels as a conclusive indication of turf-and-timber construction.

Coulston has demonstrated that roundel position varies according to the position of the depicted structure relative to the height of the column, with roundels in general becoming much less frequent and more logically positioned with increasing distance from the column base. ${ }^{27}$ By far, the most frequent position for the roundels is one crowning their supporting walls, with 18 examples (e.g., Scenes XI, XII, XX, XLIII; see figs. $1,4,5) .{ }^{28}$ In Scene XII, roundels appear too high, too low, and in approximately suitable positions for catwalks, all within centimeters of one another (see fig. 4). Coulston concludes that "the sculptors were employing this device inconsistently for purely decorative effect and were not following structural considerations." 29

\footnotetext{
${ }^{17}$ Johnson 1983, 45-7; Lepper and Frere 1988, 66; Coulston 1990a, 42. Johnston $(1983,46)$ and Coulston (1988, 144; $1990 \mathrm{a}, 42)$ see Scene XX as representing the digging of a ditch around a second pair of fortifications, but Coulston's interpretation of the low feature at the bottom of the scene as a wall is suspect. Nowhere else on the column does the top of a wall form an irregular line or have any blocks arranged vertically; see also Johnson 1983, 46.

${ }^{18}$ Coulston 1990a, 42.

${ }^{19}$ Richmond $(1982,22)$ points out that this was understood even by Latin authors, but he does not address the inconsistency between this fact and the depictions on the column.

${ }^{20}$ Coulston 1988, 145; 1990a, 43-4.

${ }^{21}$ Coulston 1988, 145; 1990a, 43-4.

${ }^{22}$ Lehmann 1926, 39-50; Coulston 1988, 29; 1990a, 42.

${ }^{23}$ Coulston 1988, 145 .

${ }^{24}$ Richmond 1982, 5; Lepper and Frere 1988, 62.

${ }^{25}$ Richmond 1982, 22; Coulston 1988, 142; 1990a, 41.

${ }^{26}$ Richmond 1982, 19-20; Coulston 1990a, 41.

${ }^{27}$ Coulston 1988, 53, 142; 1990a, 42.

${ }^{28}$ For the logical validity of various roundel positions and their distribution on the frieze, see Coulston 1988, 53, 142; 1990a, 42; Lepper and Frere 1988, 63.

${ }^{29}$ Coulston 1988, 54.
} 


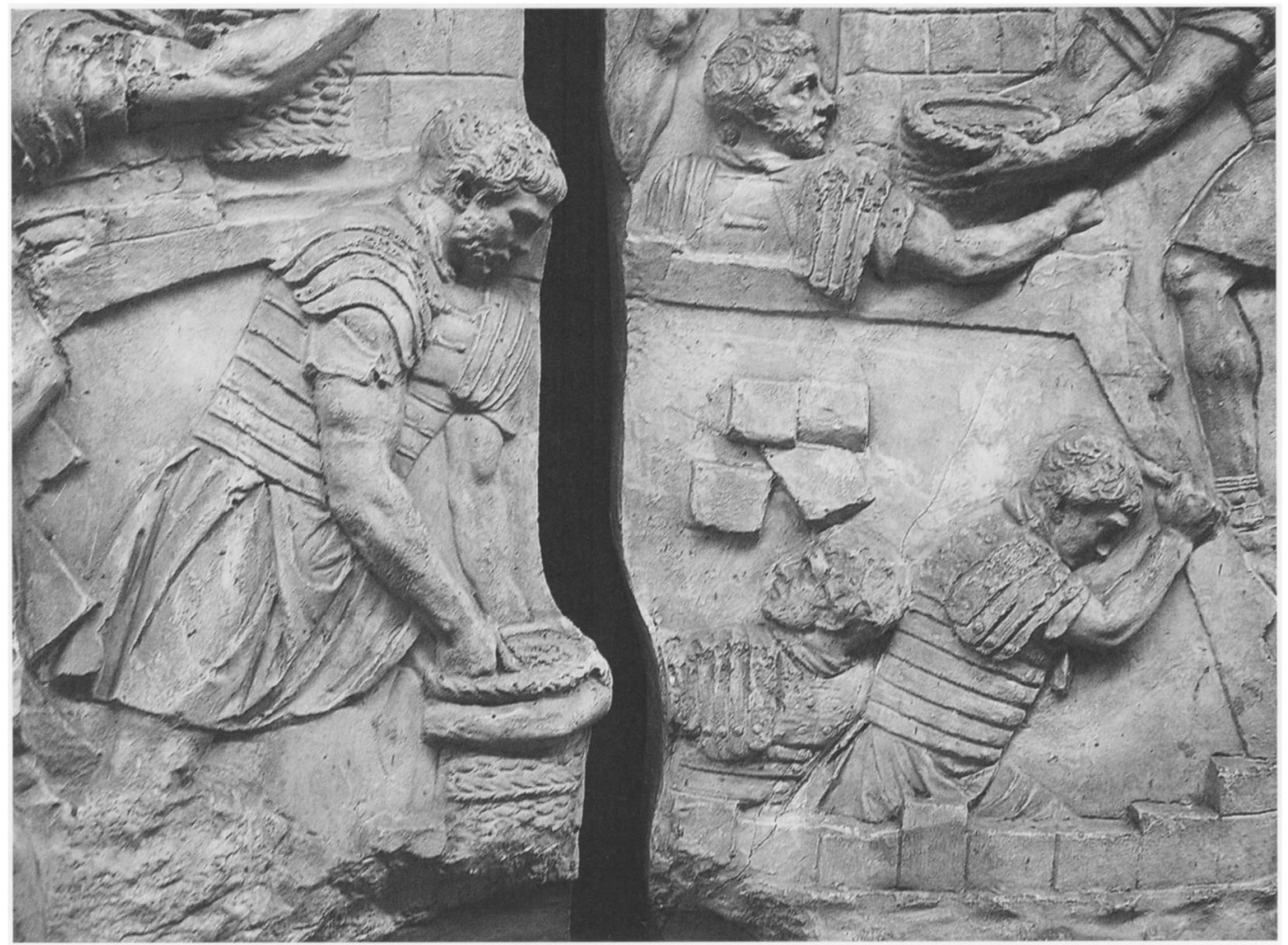

Fig. 3. Scene XX, suggested to show soldiers cutting turf (courtesy Museo della Civiltà Romana, Rome).

Even if Richmond were right in his interpretation of the roundels as timber catwalks, it does not necessarily follow that his interpretation of the walls as turf-and-timber is also correct. On 17 out of 20 possible structures (excluding bridges and unidentifiable features), roundels appear on the same supposed catwalk as what appear to be merlons, a feature usually composed of single ashlar blocks placed along stone ramparts (e.g., Scenes XI, XXVIII, CVIII; also in Dacian fortifications [Scene XCIII]) (see fig. 5) ${ }^{30}$ Roundels also appear on the same structures as rounded arches, a feature impossible in turf-and-timber (e.g., Scenes XI, XII, XXII; esp. Scenes XX and XXI, where the roundels follow the line of the arch) (see figs. 1, $5) .{ }^{31}$ The roundels as they appear on the column, therefore, are not only at times inconsistent with the internal logistics of turf-and-timber construction, they are sometimes mixed with elements inconsistent with turf-and-timber as a technique.

\footnotetext{
${ }^{30}$ Coulston 1990a, 42. For the incompatibility between timber catwalks and stone walls, see Richmond 1982, 21-2; Coulston 1988, 143-44. Richmond $(1982,21)$ interprets the merlons as timber; for the presentation of these merlons as stone blocks, see Coulston 1988, 143; 1990a, 42.
}

\section{Interpreting the Inconsistencies of the Frieze's Military Architecture}

The inconsistencies in military architecture on the frieze have traditionally been explained away by the argument that "the artists were completely ignorant of turf construction and ... impractically applied information supplied by a knowledgeable source." ${ }^{\text {22 }}$ What made it onto the marble, according to this theory, was a stylized representation, since the conception of what the roundels were meant to represent had been lost. This is certainly possible, given the likelihood that few involved with the column would ever have seen, let alone built, a turf-and-timber fort. If one assumes such a lack of conceptual understanding or interest regarding the catwalks, however, it seems reasonable to exclude the roundels as definitive evidence for a broader understanding of turf-and-timber forts. If the production team of the column did not know (or care) enough about what the roundels were meant to

\footnotetext{
${ }^{31}$ Lepper and Frere 1988, 62, 67.

${ }^{32}$ Coulston 1990a, 44; see also Richmond 1982, 5-6; Coulston 1988, 122, 147, 149-50; Lepper and Frere 1988, 56, 62-3, 117-18, 264; Williams 1998, 176-77.
} 
represent to pay attention to their position, there is no reason to believe that they would have been more concerned to include the roundels only on those camps that they intended to portray specifically as turf-andtimber. That they in fact included roundels alongside equally diagnostic features for stone only furthers the impression that the production team did not use the roundels as a distinguishing characteristic for turf-andtimber construction in particular.

Viewing the inclusion of roundels as definitively "correct," furthermore, forces a scholar to privilege the roundels above other details-in other words, to view other details as definitively "incorrect." One hundred percent of Roman camps have rectangular hatching reminiscent of stone (table 2). Merlons appear on $80 \%$ of these camps, while roundels appear on only $35 \%$; of the 16 camps with roundels, 14 also have merlons, and 4 have arched entranceways (e.g., Scenes XI, XII, XXI, XLIII) (see figs. 1, 5). Yet in these latter examples, the assumption has been that it is the roundels, even if they are "incorrectly" positioned, that indicate the construction method, meaning that the stone merlons (although more "correctly" and frequently represented), ${ }^{33}$ the arched gateways, and perhaps the hatching are all mistakes. ${ }^{34}$ The same mind-set also characterizes discussion of the relative validity of construction activities; for Scene XXXIX, for example, authors have privileged the baskets over the stone-cutting tools in arguing for turf construction, ${ }^{35}$ despite, as has been seen, the relative ambiguity of baskets in relation to turf. In arguing for turf-and-timber construction, then, modern scholars have decided which details are more important for the design of the frieze overall and have disregarded others.

The employment of the roundels should be interpreted somewhere between the "purely decorative effect" of Coulston and the unequivocal structural marker of Richmond. The roundels may have been inspired by descriptions of actual frontier practice, and indeed the production team appears to have been familiar with various aspects of actual military architecture, such as clavicula gateways, a feature of some frontier forts. ${ }^{36}$ This does not necessarily mean, however, that the roundels were meant specifically to mark turf-and-timber construction. The roundels are most prevalent in the beginning of the frieze, at

${ }^{33}$ Although the position of the merlons is generally more logical, Coulston $(1988,143-44 ; 1990 a, 42)$ notes that, in terms of strict adherence to the logistics of military campaigning, both merlons and roundels are "inappropriate features for camps" (Coulston 1990a, 42).

${ }^{34}$ For this mind-set in practice, see Lepper and Frere 1988,

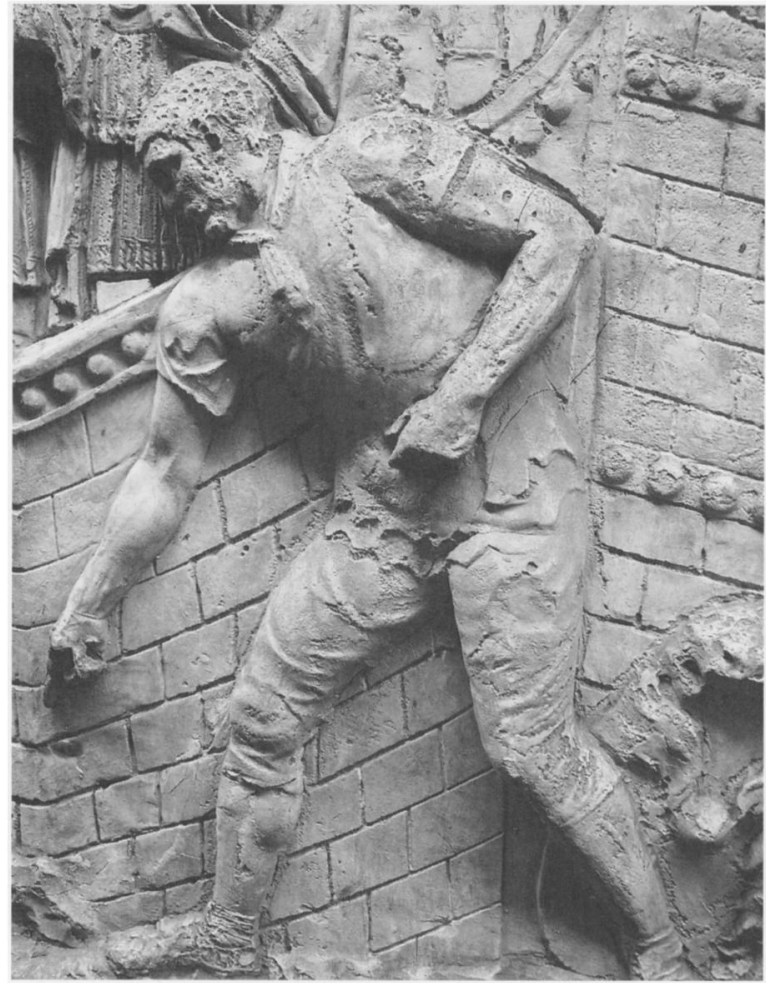

Fig. 4. Scene XII, roundels on Roman military fortifications. Note various positions of roundel lines (courtesy Museo della Civiltà Romana, Rome).

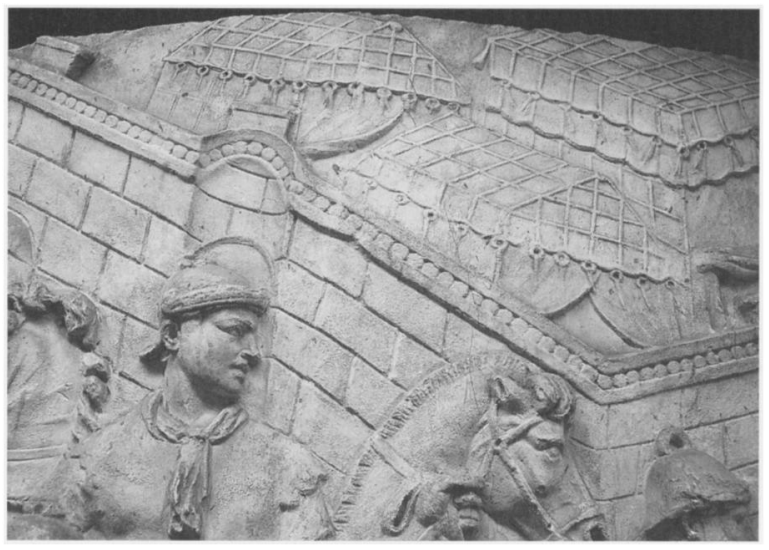

Fig. 5. Scene XXI, roundels following line of arch on Roman military fortifications. Note merlons above arch and in upper left (courtesy Museo della Civiltà Romana, Rome).

\section{$56,62,67,89,100$.}

${ }^{35}$ Lepper and Frere 1988, 88.

${ }^{36}$ Shown perhaps, for example, in Scene CXXVIII; see also Johnson 1983, 50-1; Coulston 1988, 139; 1990a, 41, 44; Lepper and Frere 1988, 67, 263. 
Table 2. Architectural Features on Roman Camps on the Column of Trajan.

\begin{tabular}{lcc}
\hline Architectural Features & Total Camps $(\mathrm{n}=46)$ & Camps with Roundels $(\mathrm{n}=16)$ \\
\hline Rectangular hatching & $46(100 \%)$ & $16(100 \%)$ \\
Merlons & $37(80.4 \%)$ & $14(87.5 \%)$ \\
Roundels & $16(34.8 \%)$ & - \\
Arched entranceways & $7(15.2 \%)$ & $4(25.0 \%)$ \\
\hline
\end{tabular}

a point where there seems to be an interest in establishing the flavor of the setting for the narrative. Just as the forts, watchtowers, palisades, and piled logs of Scenes I and II effectively convey the idea of "the frontier," the roundels characterize their constructions as belonging to another place and time, outside the ancient viewer's everyday urban experience. The roundels evoke the character and setting of the camps and fortifications rather than delineating their construction technique.

\section{Beyond Turf-and-Timber: A Thematic Approach to} Military Architecture on the Frieze

One essential fact has become lost: the military structures as depicted do not look like turf-and-timber constructions-they look like stone. There is no apparent effort on the part of the production team to distinguish the construction technique used in Roman military architecture from that used in Roman cities or towns. Exterior walls and interior buildings in both military and civilian contexts are all depicted using the same rectangular block hatching (see figs. 1, 2). Nor is there any obvious consistent attempt to distinguish construction techniques among types of fortifications. ${ }^{37}$ While scholars have tried to discern technical distinctions between the depictions, ${ }^{38}$ discrete types of fortification are not readily apparent. ${ }^{39}$ All military architecture is depicted with the same type of rectangular block wall, and elements of more permanent structures mix with those of the ephemeral.

Yet as Coulston points out, given the wealth of careful detail throughout the column, it seems likely that, had the production team wished to distinguish stone walls from turf ramparts, they could have done so. ${ }^{40}$ Scholars have long noted the abundance of minuscule detail and careful variation on the frieze; it appears

\footnotetext{
${ }^{37}$ Lepper and Frere 1988, 55-6. For the same issue regarding the Column of Marcus Aurelius, see Hanoune 2000, 208.

${ }^{38}$ Coulston 1988, 137-38; 1990a, 39; Lepper and Frere 1988, esp. 65-6.

${ }^{39}$ Coulston 1988, 137-38; 1990a, 39, 41; Lepper and Frere 1988, 55-6, 103, 263. Lepper and Frere $(1988,264)$ "prefer the
}

that the production team had access to a highly refined degree of information, and that at times they actively used this information to paint a very detailed, differentiated picture. One can only conclude that for whatever reason, they did not choose to pursue a similar vein with the Roman military architecture.

It can be no coincidence, as some have maintained, that the technique employed for this architecture looks like stone. It could not have escaped the production team that these rectangular blocks would be reminiscent of cut-stone masonry. Not only would they most likely have been familiar with the broader Mediterranean canon of representing ashlar masonry, but they themselves would have been surrounded by a city replete with examples of ashlar masonry, either real or simulated in marble and stucco facings. ${ }^{41}$ Nor does another proposed solution-that faced with a void as to how the forts were constructed, the sculptors simply fell back on the Hellenistic convention of ashlar masonry ${ }^{42}$-seem tenable. It is difficult to believe that such a void could have been allowed to exist, or that an ad hoc solution would have gained such wide acceptance, approval, and above all consistent application, especially over so much surface area of the frieze.

It would perhaps be wise to abandon the acrobatics of speculating on what the production team could have possibly known or not known in favor of pursuing the simplest solution. It seems best to trust the production team, to imagine that they consistently portrayed Roman military architecture as if made of stone because that is what they intended to do. Whether or not the various members of the production team were familiar with turf-and-timber construction, it is clear that for the military architecture, the production team made a conscious and definitive choice to employ consistently

\footnotetext{
explanation that the sculptors were not sufficiently briefed on

the distinctions between permanent and temporary work."

${ }^{40}$ E.g., by using closer-hatched lines (Coulston 1988, 147;
the distinctions between permanent and temporary work." 1990a, 44).

${ }^{41}$ Coulston 1990a, 44; Adam 1994, 146.

${ }^{42}$ Coulston 1990a, 44.
}$$
\text { Coulston 1990a, } 44 .
$$ 
the same technique used elsewhere (not only on the Column of Trajan but in the broader Mediterranean and Roman artistic tradition) to depict ashlar masonry. This choice probably had little to do with confusion and much more to do with a conscious desire to harness the evocative power of that method of construction.

Cut-stone masonry had important connotations in the Roman world. Actual ashlar masonry required considerable resources and technical skill, and by the time of Trajan, the Roman genius for mass-production had fueled the standardization and extension of cut-stone masonry (and its imitations) even into the provinces. ${ }^{43}$ The widespread employment of ashlar masonry would be, therefore, an excellent means of calling to mind the technical expertise and efficiency of the Roman empire. The practical benefits of stone construction, furthermore, imbued the technique with connotations of permanence, strength, and cultural achievement. Genuine stone construction or facing protected buildings from fire and delayed their decay. Augustus' promotion of stone construction in Rome itself, for example, not only improved the aesthetics of the city but also prevented the spread of destructive fires and ensured the physical permanence of the city. The use of stone construction for the representations of Roman military architecture on the frieze would elicit these same connotations and present a clear message of technical skill, cultural sophistication, and the permanence of the Roman army in Dacia. ${ }^{44}$

\section{CONSTRUCTING CIVILIZATION: ARCHITECTURE, CIVILIAN SETTLEMENTS, AND THE DACIAN ENEMY}

The depictions of military architecture on the Column of Trajan frieze have traditionally been interpreted as a graphic essay, however confused and confusing, that attempted to document the impressive construc-

\footnotetext{
${ }^{43}$ MacDonald 1986, 127, 173-74; Adam 1994, 128, 131, 135, 141-42; Gros 1996, 37; Anderson 1997, 147, 166-67, 177-79; Wilson Jones 2000, 155. The particular concern for stone construction can be seen in Roman Carthage, where stone was imported for official monuments so that these structures could be rendered in opus reticulatum, a construction technique that the local Punic polygonal masonry did not anticipate and for which their spoils were therefore unsuitable (Rakob 2000, 79-80).

${ }^{44}$ It is admittedly possible that the rectangular blocks on the frieze are meant to represent bricks. This is unlikely, however. On the Column of Trajan, the same rectangular pattern is used for both military camps and city fortification walls, and the latter most likely would have been represented as stonebuilt. Although bricks were increasingly used in actual Trajanic architecture at the time of the column, Roman architecture had long been (and would remain) an architecture characterized by an outward appearance of cut stone, despite var-
}

tions erected by the Roman army on campaign in Dacia. A comprehensive analysis of all Roman military fortifications on the frieze, however, reveals distinct trends that are consistently upheld through the length of the frieze, despite their blatant inconsistency with actual architectural practice. The clearest example of this phenomenon is the constant practice of rendering temporary Roman military fortifications as if they were built of stone, rather than the admittedly more logical turf-and-timber. While such rendering makes little documentary sense, it would immediately associate the fortifications with broader connotations of the superiority of cut-stone masonry and situate the fortifications within a conceptual framework of a permanent, superior Roman presence in Dacia. This fits well within recognized broader thematic concerns of the Column of Trajan.

All of this suggests that, despite archaeologists' hopes, thematic concerns were generally privileged over documentary accuracy in the depictions of architecture on the Column of Trajan frieze. Acknowledging this phenomenon for the military architecture and keeping in mind the broader statistical trends mentioned above allows one similarly to reevaluate the depictions of civilian and Dacian architecture on the frieze.

The emphasis on stone construction seen in the military architecture is echoed in the depictions of the architecture of peaceful civilian settlements. Nearly all prominent buildings in the civilian settlements are depicted as specifically built of stone (see fig. 2). The only real exceptions are the buildings of the settlement around Apollodorus' bridge over the Danube (Scene C) (fig. 6). ${ }^{45}$ The inclusion here of pegged buildings and a partially wooden amphitheater ${ }^{46}$ is probably a deliberate statement about the level of sophistication of the town, since at this point in the narrative, Trajan

ied internal construction materials (MacDonald 1986, 250; Coulston 1988, 147; Adam 1994, 128, 135, 141-42; Anderson $1997,147-48,155,168)$. At the time of the construction of the Column of Trajan, imperial architects were beginning to experiment with exposed brick facades; this was relatively new, however, and the lasting influence of the appearance of cut stone can be seen in the continual application of stucco over walls whose original appearance featured decorative patterns in different types of brick (Adam 1994, 133).

${ }^{45}$ For the identification of this scene, see Turcan-Déléani 1958, 150; Coulston 1988, 26; Lepper and Frere 1988, 149-51; Coarelli 2000, 162.

${ }^{46}$ Several authors characterize the amphitheater as wooden (Davies 1920, 4; Coulston 1988, 25; Lepper and Frere 1988, 152; Coarelli 2000, 164), but no source I have found addresses the vaulted arches of the lower story. Lepper and Frere (1988, 152) suggest that the wooden construction indicates that the settlement is a legionary fortress. 


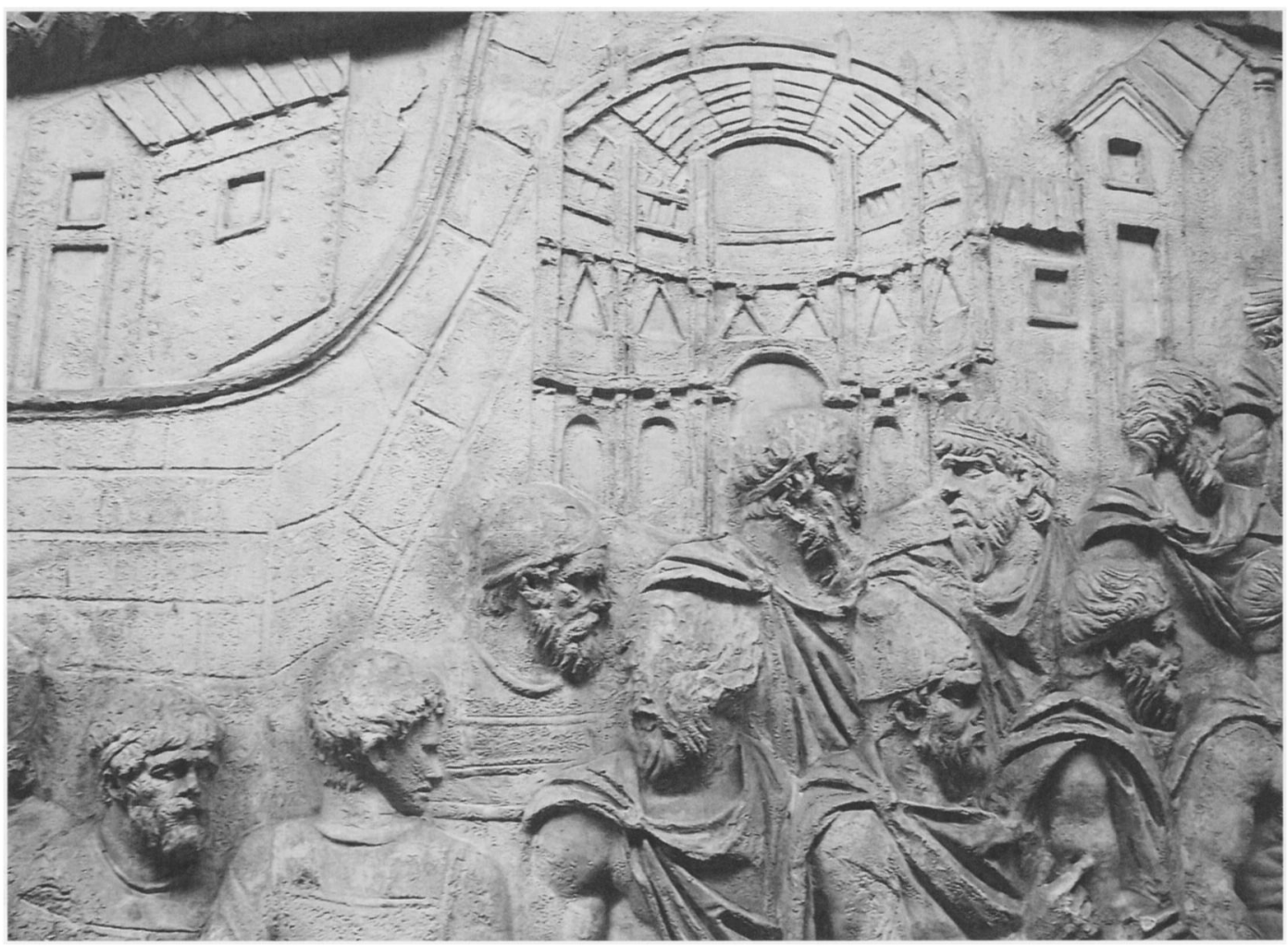

Fig. 6. Scene C, wooden buildings in the civilian settlement around Apollodorus' bridge over the Danube (courtesy Museo della Civiltà Romana, Rome).

has progressed through more prosperous established towns to this new settlement at the edges of the uncontrolled Dacian territory. ${ }^{47}$ The site, located at the border along the Danube, thus may be seen as the exception that proves the rule regarding the importance of stone construction for the characterization of mature Roman civilian architecture.

The connection between settlements depicted on the frieze and Roman urbanity established through construction material is reinforced by the prominence of buildings-such as amphitheaters, prostyle temples, and monumental arches-that immediately demonstrate the connection between the peaceful towns and the Roman way of life (see figs. 2, 6, 7, 8). Many of these buildings and their settlements, including those across the Danube (Scene C), are notably aligned along the west vertical axis of the Column of Trajan, connecting these settlements not only to Rome but also to

\footnotetext{
${ }^{47}$ For the transition between civilized and barbaric territory, see Lepper and Frere 1988, 134.

${ }^{48}$ Galinier $(2007,88-91)$ describes this phenomenon and briefly summarizes the theme of this axis as "Trajan et la metamorphose de l'espace dace" (Galinier 2007, 91). Numerous scenes of military construction are included on this axis (Galinier 2007, 88-91), further linking the civilian settlements to mili-
}

one another. ${ }^{48}$ The combination of stone construction and elaborate civil architecture often serves as a backdrop to scenes of sacrifice or provisioning the army (see figs. 2, 8), emphasizing the prosperity enjoyed by those towns that agree to participate with Trajan in the Roman way of life. In Scene LXXXVI (see fig. 8), for example, elaborate urban architecture, including a sophisticated theater, frames a scene in which citizens join with Trajan and his soldiers in sacrificing to the gods. This thematic significance may explain the particular appearance of the civilian settlements on the Column of Trajan frieze.

The depiction of both military and civilian Roman architecture can be compared to the depiction of Dacian architectural structures on the frieze. While peaceful civilian settlements feature recognizably Roman building types, Dacian buildings are often given strange, barbaric architectural forms. ${ }^{49}$ Structures

tary architecture. Scenes of battle are notably de-emphasized on this axis (Galinier 2007, 90-1), perhaps increasing the sense of peace and prosperity of the civilian settlements.

${ }^{49}$ As for the military architecture, there has been substantial debate regarding the extent to which the Dacian architecture of the frieze can be connected to actual architectural practice in Dacia, especially given the impressive Dacian architectural 


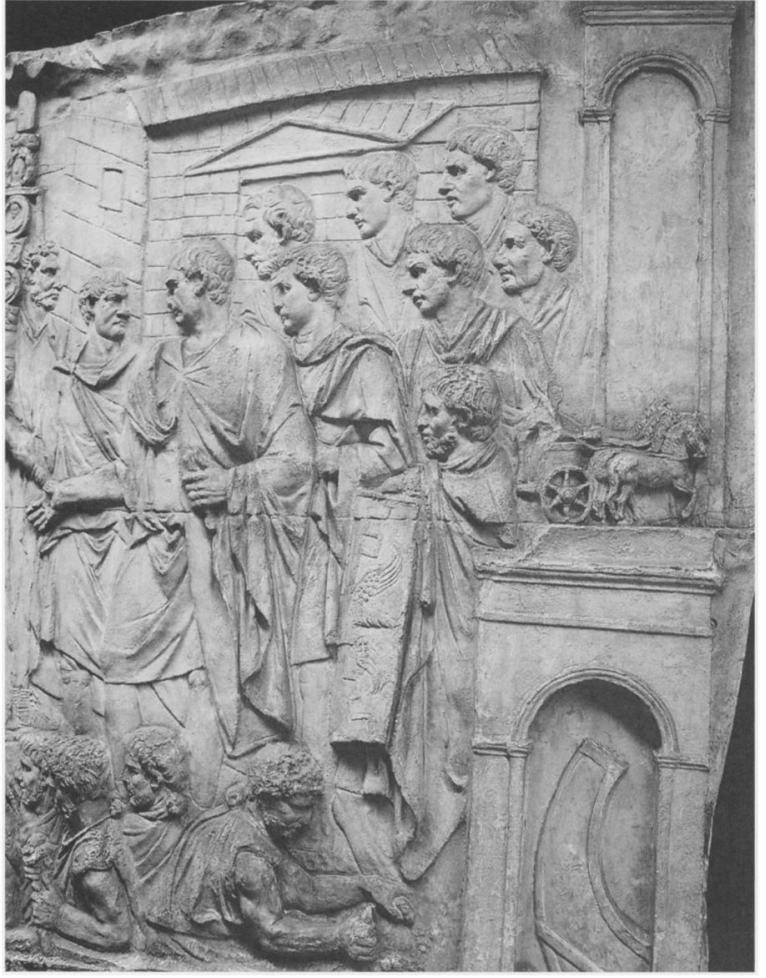

Fig. 7. Scene XXXIII, storage facilities(?) and two monumental arches in the harbor of a civilian settlement (courtesy Museo della Civiltà Romana, Rome).

on stilts, for example, are striking features repeated throughout the frieze in association with Dacian occupation (e.g., Scenes XXV, LVII) (figs. 9-11). Other strange forms include rectangular towers with exaggerated openings (Scenes LXII, CXI, CXIII, CXV, CXVI, CXXI, CXXIV) (fig. 12) and gabled structures that appear above Dacian strongholds' gateways (Scenes XCIII, CXI, CXIX, CXXIV, CLI) (fig. 13). Such Dacian gateways are exclusively rectangular, in contrast to the typically arched gateways of Roman fortifications. Curved or cylindrical forms are given particular prominence in depictions of Dacian architecture on the frieze. Notable examples include the round wooden palisade in Scene XXV (see fig. 9), ${ }^{50}$ the four mysterious cylindrical structures with crescent projections and distinctive moldings in Scene LXII, ${ }^{51}$ and the

tradition leading up to the Dacian Wars (Davies 1920; Rossi 1971; Coulston 1988, 22-3, 151-52, 154; 1990a, 46-7; Lepper and Frere 1988, 2, 19, 27, 72, 105-6, 108, 118-20; Stefan 2005, esp. 40-1, 52-8, 600-25; Galinier 2007, 108-12). For an introduction to recent archaeological work on architecture in Dacia, see, e.g., Oltean and Hanson 2001; Hanson and Haynes 2004; Stefan 2005; Wilkes 2005; Oltean 2007. It must be remembered, however, that no detailed understanding of ac-

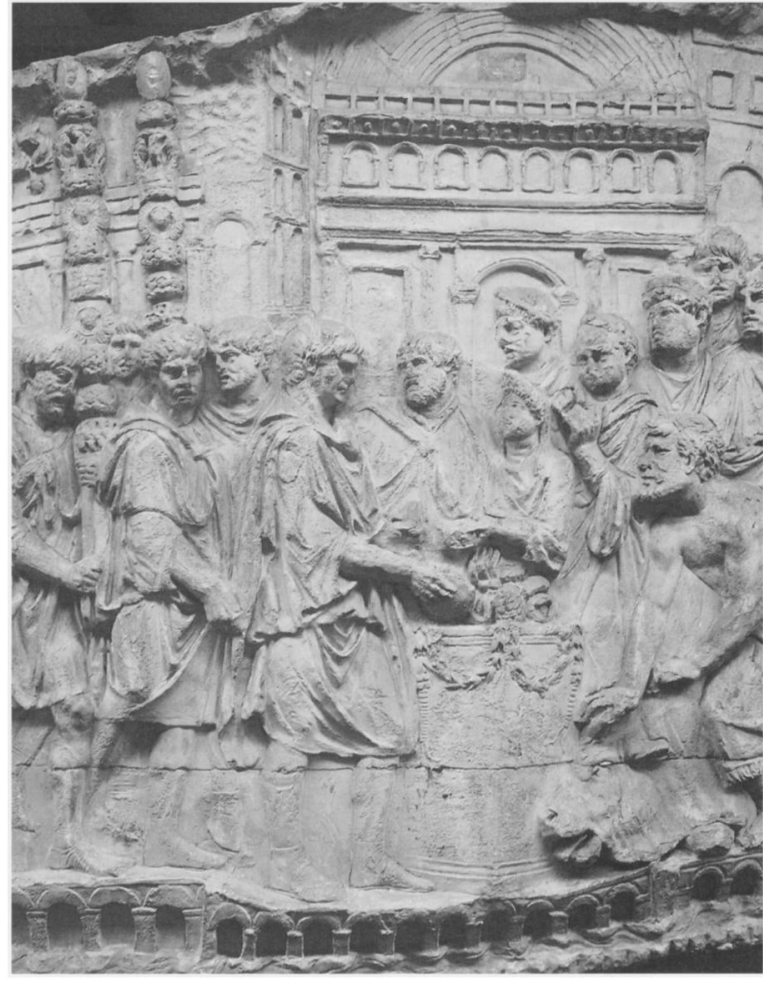

Fig. 8. Scene LXXXVI, Trajan leading local population of a civilian settlement in sacrifice (courtesy Museo della Civiltà Romana, Rome).

several cylindrical buildings of Scenes CXIX-CXXII (see figs. 13, 14). Clearly these round structures are unlikely to be mistaken for Roman edifices.

Dacian architectural structures on the frieze often appear illogical, either in form or in their combination of building materials. In Scene XXV, an ashlar building rises on thin wooden stilts (see fig. 9); in Scene LVII, the entrance of a similar building opens out precariously into thin air (see fig. 10). The palisade of Scene LXVII does not clearly surround or protect anything (fig. 15), and in general, Dacian fortifications feature gaping entrances that undermine the function of their imposing walls (see figs. 13, 15). These strange, illogical forms differentiate Dacian architecture and settlements from Roman and cast the Dacian culture in a comparatively unfavorable light.

tual contemporary Dacian architectural practice would have been necessary to appreciate the appearance of Dacian architecture on the frieze.

${ }^{50}$ For discussion of this scene and the Dacian identification of this architecture, see Lepper and Frere 1988, 72; Coulston 1990a, 46; Coarelli 2000, 69; Galinier 2007, 108-12.

${ }^{51}$ For discussion of the identification of these buildings, see Coulston 1988, 154; 1990a, 47; Lepper and Frere 1988, 104. 
Construction materials further differentiate Dacian architectural practice from Roman. As mentioned above, Dacian architectural structures are more frequently shown as wooden than are Roman structures. Discounting bridges, palisades, and siege engines, which are logically only shown as wooden for both cultures, there are 39 Dacian wooden architectural structures, but only 11 Roman. While the depiction of stone construction is relatively constant for both Roman and Dacian structures, ${ }^{52}$ wooden construction is often exaggerated in architectural structures associated with Dacian culture. Dacian buildings frequently feature both clearly emphasized planks and pegs, on both the walls and the roof, with some buildings also featuring slats (e.g., Scenes XXV, LIX, CXIX, CLI; see figs. $11,14)$. The employment of wooden construction for structures associated with Roman culture is also clearly linked to the narrative. The first specifically wooden Roman building does not appear until near the bridge along the Danube (Scene $\mathrm{C}$ ), at the border between civilized Roman settlements and the more dangerous Dacian territory. The first Dacian wooden building, in contrast, appears in Scene XXV, with no obvious narrative impetus. Dacian structures also tend to be simpler than their Roman counterparts, with fewer added details and with a more limited range of features.

The fact that one-fourth of Dacian architectural structures are either on fire or directly threatened by fire underscores both their wooden construction material and its technical disadvantages, while vividly creating a sense of transience and doom. Torches are raised to roofs and walls, and flames leap out of doors and windows (see figs. 10, 11, 13, 14). Both Romans and Dacians are shown inflicting this damage, but while the Roman soldiers are also shown constructing new architecture, Dacians only destroy or abandon their buildings, or, at most, fruitlessly defend them. The one instance in which any Dacian attempt at construction is even implied is Scene LXVII,,$^{53}$ and there, it is specifically wooden construction.

In several scenes, the destruction of Dacian architecture is explicitly equated with the destruction of Dacian civilization as a whole. In Scenes CXX-CXXII, for example, a fortification wall provides a compositional axis, where the obliteration of Dacian architecture at

\footnotetext{
${ }^{52}$ The one exception is the odd polygonal hatching seen in the Dacian fortifications of Scenes CXIII-CXVI. This hatching has been seen as an attempt to illustrate the murus Dacicus construction method (Rossi 1971, 34; Coulston 1988, 152, 154; 1990a, 47; Lepper and Frere 1988, 108, 165; for the identification of the fortifications as murus Gallicus, see Richmond $1982,41)$. The hatching also has been seen as patchwork repairs following the forced dismantling of Dacian fortifications at the end of the First Dacian War; for discussion and
}

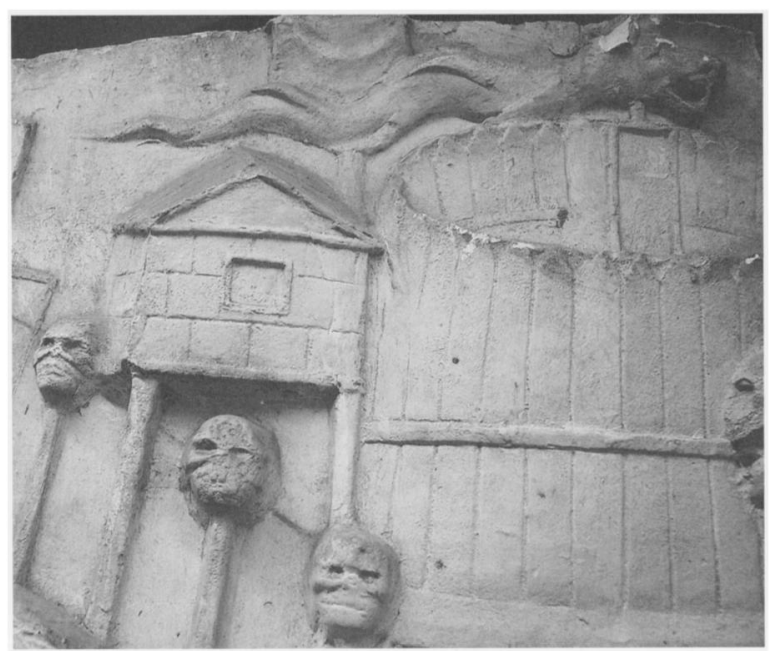

Fig. 9. Scene XXV, architecture inside Dacian fortifications. Note building on stilts (courtesy Museo della Civiltà Romana, Rome).

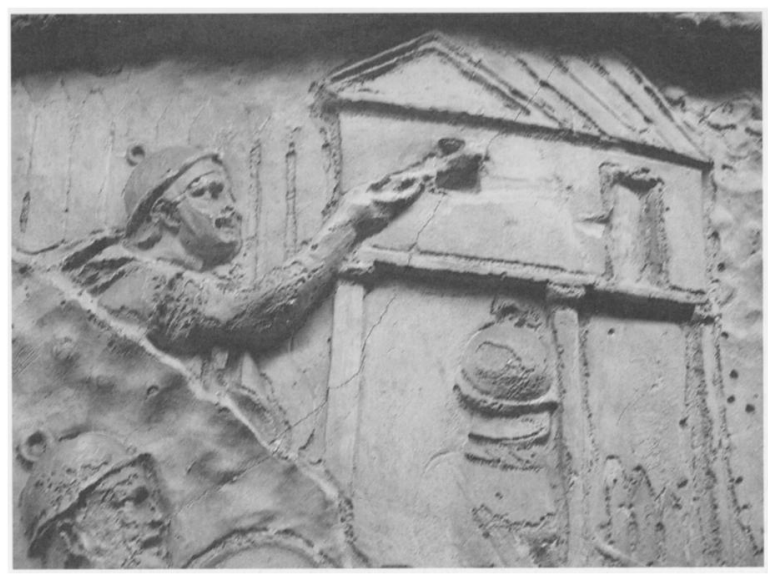

Fig. 10. Scene LVII, destruction of Dacian building on stilts (courtesy Museo della Civiltà Romana, Rome).

Dacian hands on one side reflects the destruction of the Dacians themselves, again at their own hands, on the other (see fig. 13) ${ }^{54}$ By Scenes CL-CLIII, some of the final scenes of the frieze, even stone buildings of the Dacians burn as the Roman soldiers methodically complete their work of conquest. The message sent by

an argument against this suggestion, see Coulston 1988, 153. Coulston $(1988,153 ; 1990 \mathrm{a}, 47)$ sees the masonry as reflecting the archaic associations of republican polygonal masonry in Italy. The use of polygonal masonry for the climax of Dacian strongholds certainly characterizes these fortifications as barbaric and strange; it should be noted that in Scene CXVI, the same fortifications are rendered as ashlar masonry.

${ }^{53}$ Hölscher 1991b, 291.

${ }^{54}$ For a discussion of the narrative of this scene and the 


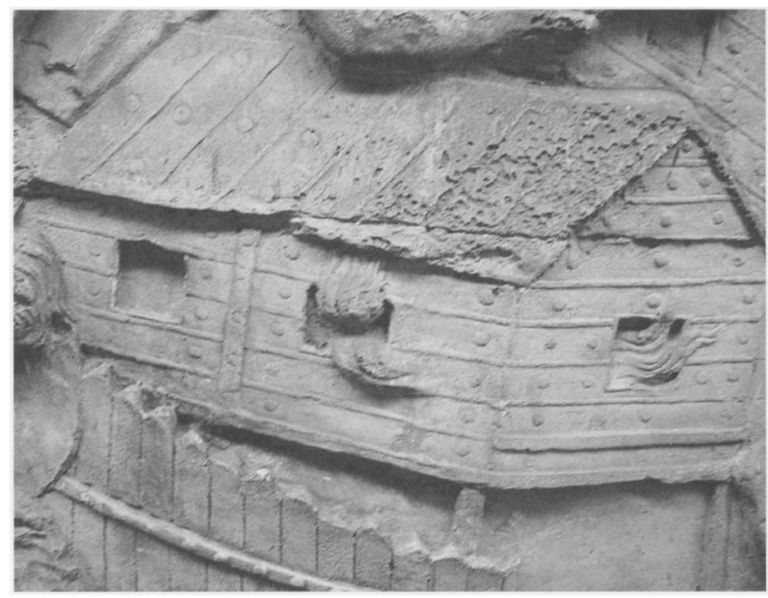

Fig. 11. Scene XXV, destruction of Dacian building on stilts. Note planking, pegs, and burning indicating wooden construction (courtesy Museo della Civiltà Romana, Rome).

the contrast in architecture between Roman and Dacian settlements would be clear: loyalty to the Roman state brought civilization, prosperity, and peace, while barbaric resistance brought destruction and death.

\section{CONCLUSIONS}

The architectural depictions on the Column of Trajan frieze cannot be treated as topographic signposts or incidental background filler. Rather, the manner in which architecture is depicted on the frieze plays an important role in the thematic impact of the monument as a whole. Architectural depictions emphasize the skills and permanence of the Roman military and Roman culture, and they paint Dacian culture as primitive, foreign, and transient. This is accomplished through both architectural forms and construction material. Stone construction and sophisticated urban prosperity explicitly link military activity and peaceful settlements with Rome, while wooden construction and architectural destruction illustrate the obliteration of the rebellious Dacian culture. This use of architecture and its message is not limited to the Column of Trajan, however. Rather, the column

probability that it shows the doling out of poison, see Coulston 1988, 29; 1990b, 297; Lepper and Frere 1988, 168-69; Coarelli 2000,192 . Regardless of the exact narrative event, the sprawling Dacian bodies make clear its outcome.

${ }^{55}$ Hanoune 2000.

${ }^{56}$ Some may argue that this contrast with the Column of Trajan is merely a reflection of historical reality, in that Germanic tribes did not build architecture on the same scale as in Dacia. Such an argument, however, seems overly simplistic. Like the Column of Trajan, the Column of Marcus Aurelius has been plagued by debates over the relationship between representation and historicity (Pirson 1996, 139-41, 171-77; Zanker

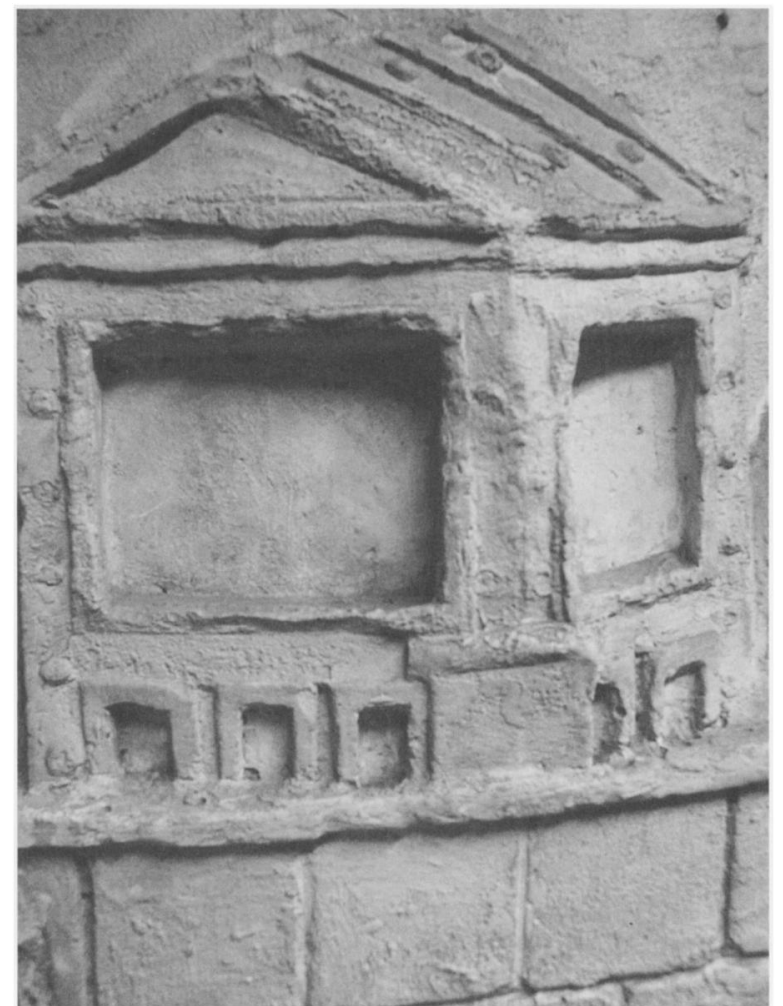

Fig. 12. Scene LXII, Dacian tower building inside fortifications (courtesy Museo della Civiltà Romana, Rome).

is but one example of a distinct trend in Roman state relief, where depictions of architecture were used to represent a foreign culture and to differentiate it clearly from Roman culture.

Examples of this phenomenon are numerous. In the Great Trajanic Frieze, for example, two reed huts help mark the defeated barbarians as inherently inferior to the Roman victors. Similar reed huts also appear on the Column of Marcus Aurelius. ${ }^{55}$ In contrast to the Column of Trajan, however, the Column of Marcus Aurelius features no examples of complex indigenous architecture ${ }^{56}$ as with other elements of the frieze, the inferiority of the barbarian enemy is painted in clear, broad strokes. ${ }^{57}$ The huts are almost exclusively on fire

2000b, 171-73). For criticism of historical approaches and an argument for an appreciation of the thematic and symbolic aspects of the representations, see Dillon 2006, esp. 244.

${ }^{57}$ While not entirely absent, construction scenes of the Roman military are similarly limited to only two examples (Pirson 1996, 140). The omission of military architecture and inclusion of barbarian architecture may both be connected to arguments by Pirson $(1996,149)$, who suggests that the Roman army is portrayed on the Column of Marcus Aurelius as victorious through inevitable superiority (rather than technical expertise), accomplishing its victory without effort over a patently inferior enemy. 


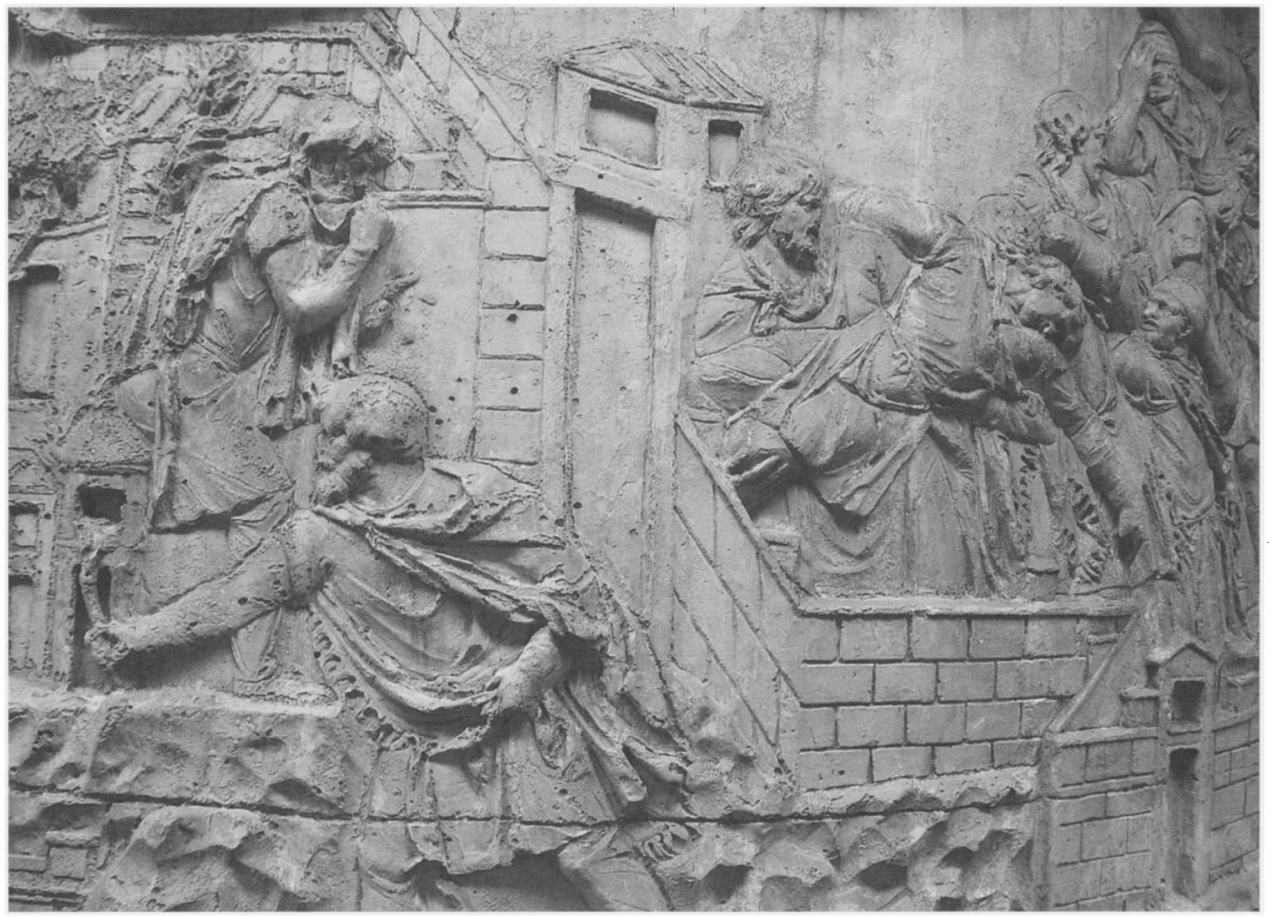

Fig. 13. Scenes CXIX and CXX, gateway to Dacian fortifications. Note destruction of Dacian architecture to left of gateway and death of Dacians to right (courtesy Museo della Civiltà Romana, Rome).

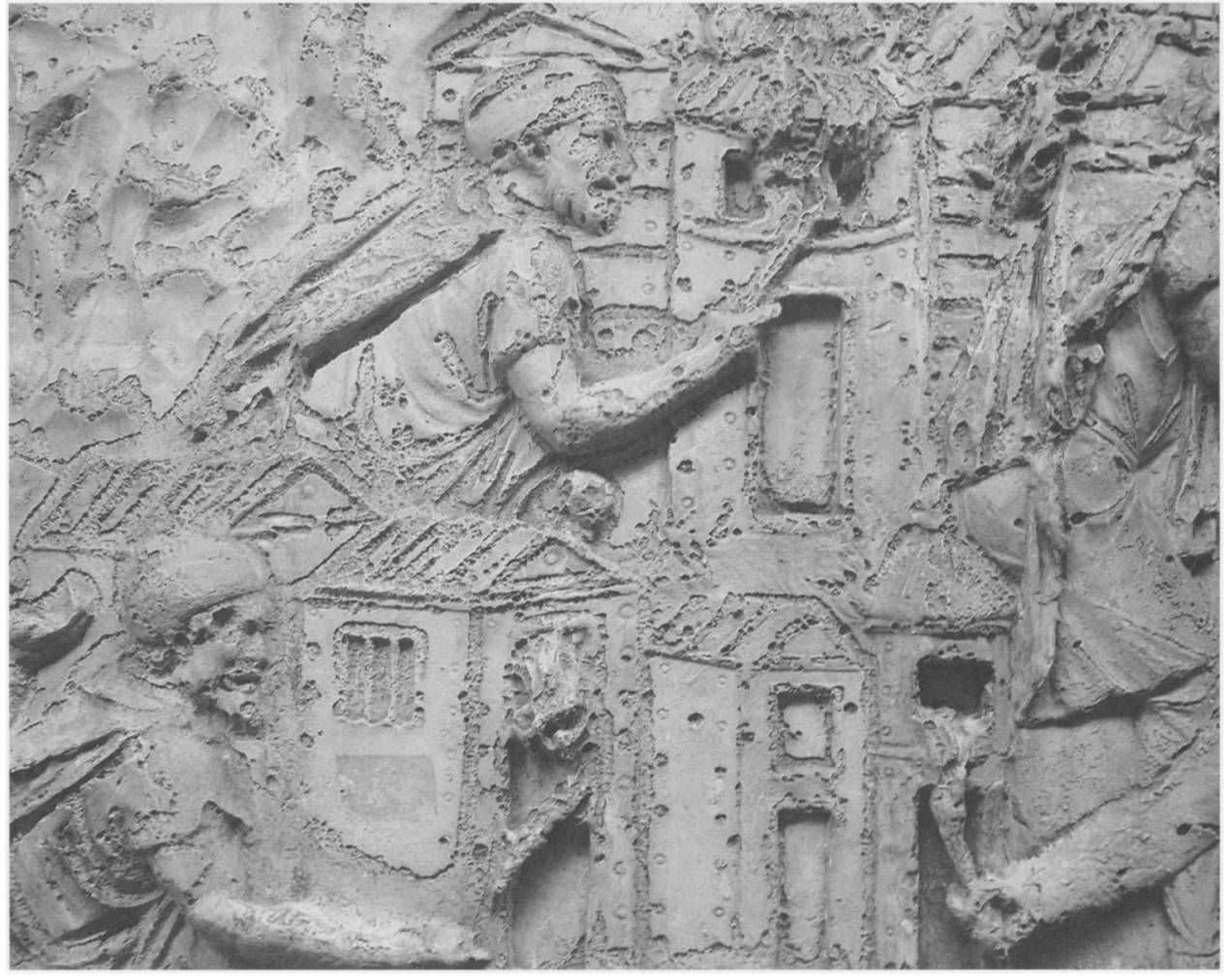

Fig. 14. Scene CXIX, destruction of Dacian architecture at the hands of Dacians. Note the two cylindrical buildings (courtesy Museo della Civiltà Romana, Rome). 
or abandoned, their destruction serving as the vivid setting for scenes of carnage, murder, and rape.$^{58}$ On the Column of Marcus Aurelius, architecture thus plays an integral role in both the characterization and the symbolic destruction of what the monument portrays as an inferior barbarian culture.

A more complicated example is that of the Arch of Septimius Severus in Rome. Like the Column of Trajan (but unlike the Column of Marcus Aurelius), the Severan arch commemorates a war waged against an urbanized enemy and features prominent depictions of foreign architecture. More specific similarities between the Column of Trajan and the Arch of Septimius Severus include the emphasis on representations of besieged cities with impressive fortifications and on Roman military architecture, represented on the arch by both camps and elaborate siege engines. ${ }^{59}$ There appears to have been some attempt on the arch to evoke an indigenous flavor for the architecture, seen perhaps in the conical tower in Panel I, the flat-roofed and pillar-like buildings in Panel III, and the structure with crowning orb in Panel IV ${ }^{60}$ This inclusion of specifically foreign architecture would have helped avoid comparisons to the emperor's other recent victory, the ideologically problematic civil war. By portraying the cities as urban and advanced, furthermore, the arch would have presented the Parthian cities as something desirable to incorporate within the empire, despite the fact that some of the cities supposedly conquered in the war, such as Babylon, had long passed their days of glory. ${ }^{61}$

The architectural depictions of the Column of Trajan are not, therefore, an isolated phenomenon; they are instead part of a broader artistic tradition that connected Roman culture closely to its architecture. Within this visual tradition, Roman culture was urban, architecturally sophisticated, and visually distinct. Association with Rome could be depicted through association with specific types of architecture; conversely, architecture could be used to characterize a people as set apart from Roman culture and send important messages regarding the supremacy of Rome. This conceptualization and use of architecture in art has important implications for how the ancient Romans

\footnotetext{
${ }^{58}$ Pirson 1996, 142, 166-67.

${ }^{59}$ The inclusion of siege imagery would also help demonstrate Roman cultural superiority. Roth $(2006,61)$ has argued that Livy uses siege warfare to characterize Roman culture as superior to both barbaric cultures (who are not technically capable of waging siege warfare) and Eastern cultures (who are too soft and undisciplined to properly wait out a siege). Both examples can be contrasted with the stoic and disciplined Romans who execute the siege.

${ }^{60}$ I follow here Brilliant's (1967, 175-76; cf. Picard 1962)
}

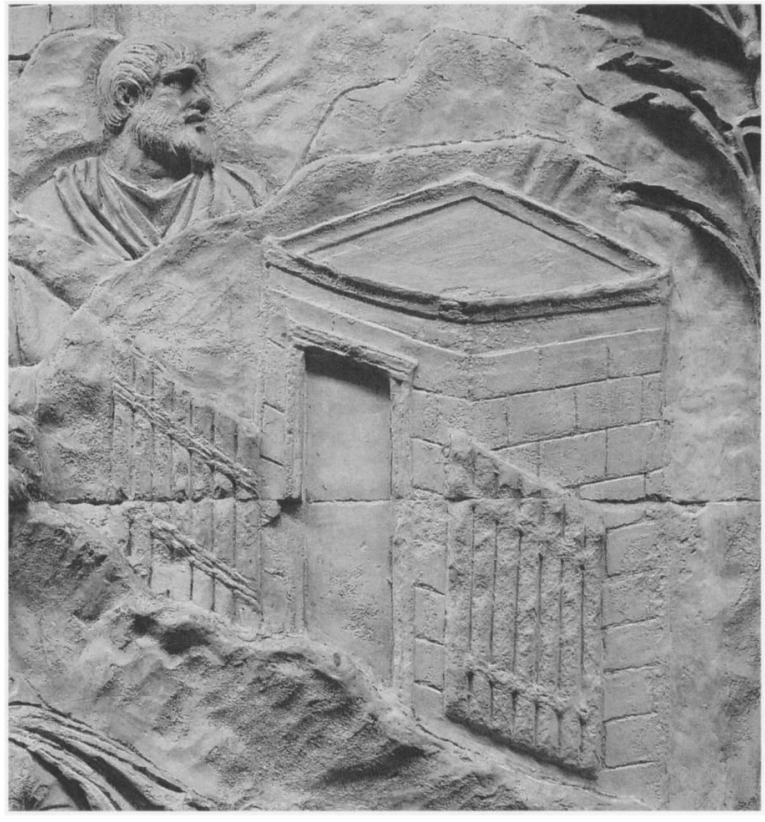

Fig. 15. Scene LXVII, Dacian palisade (courtesy Museo della Civiltà Romana, Rome).

viewed their own culture and the cultures of the people they ruled. Architectural backdrops in imperial monuments are not just backdrops, then; they are essays in cultural interaction.

\author{
DEPARTMENT OF CLASSICS \\ 212 MURPHEY HALL \\ UNIVERSITY OF NORTH CAROLINA AT CHAPEL \\ HILL \\ CHAPEL HILL, NORTH CAROLINA 27599-3145 \\ ETHILL@UNC.EDU
}

\section{Works Cited}

Adam, J.-P. 1994. Roman Building: Materials and Techniques. London: B.T. Batsford.

Anderson, J.C., Jr. 1997. Roman Architecture and Society. Baltimore: The Johns Hopkins University Press.

Brilliant, R. 1967. The Arch of Septimius Severus in the Roman Forum. MAAR 29. Rome: American Academy in Rome.

system for numbering the panels on the arch. As for the architectural depictions on the columns, scholarship on the architectural depictions of the Arch of Septimius Severus has generally focused on the historical identification of the cities. For descriptions of the cities and discussions of their historical identification, see, e.g., Picard 1962; Brilliant 1967, 30, 171215, 223-32; Lusnia 2006, 272, 276-77, 282-88.

${ }^{61}$ For discussion of the state of the city of Babylon and its significance during the Severan Parthian Wars, see Brilliant $1967,180-81$. 
Cătăniciu, I.B. 1981. Evolution of the System of Defence Works in Roman Dacia. BAR-IS 116. Oxford: British Archaeological Reports.

Cichorius, C. 1896. Die Reliefs der Traianssäule. Vol. 2. Berlin: Georg Reimer.

. 1900. Die Reliefs der Traianssäule. Vol. 3. Berlin: Georg Reimer.

Claridge, A. 1993. "Hadrian's Column of Trajan?” JRA 6: 5-22.

1998. Rome. Oxford Archaeological Guides. Oxford: Oxford University Press.

Clarke, J. 2003. Art in the Lives of Ordinary Romans: Visual Representation and Non-Elite Viewers in Italy, 100 BC-AD 315. Berkeley: University of California Press.

Coarelli, F. 2000. The Column of Trajan. Rome: Editore Colombo.

Coulston, J.C.N. 1988. "Trajan's Column: The Sculpting and Relief Content of a Roman Propaganda Monument." Ph.D. diss., Newcastle University.

_ 1990a. "The Architecture and Construction Scenes on Trajan's Column." In Architecture and Architectural Sculpture in the Roman Empire, edited by M. Henig, 39-50. Oxford: Oxford University Committee for Archaeology.

1990b. "Three New Books on Trajan's Column." JRA 3:290-309.

Davies, G.A.T. 1920. "Topography and the Trajan Column." JRS 10:1-28.

Depeyrot, G. 2007. Optimo Principi: Iconographie, monnaie et propagande sous Trajan. 3 vols. Wetteren: Moneta.

Dillon, S. 2006. "Women on the Columns of Trajan and Marcus Aurelius and the Visual Language of Roman Victory." In Representations of War in Ancient Rome, edited by S. Dillon and K. Welch, 244-71. Cambridge: Cambridge University Press.

Galinier, M. 2007. La Colonne Trajane et les Forums Impériaux. Collection de l'École Française de Rome 382. Rome: École Française de Rome.

Gros, P. 1996. L'architecture romaine du début du IIIe siècle av. J.-C. à la fin du Haut-Empire. Vol. 1, Les monuments publics. Paris: Picard.

Grunow, M.D. 2002. “Architectural Images in Roman State Reliefs, Coins, and Medallions: Imperial Ritual, Ideology, and the Topography of Rome." Ph.D. diss., University of Michigan.

Gudea, N. 1979. "The Defensive System of Roman Dacia." Britannia 10:63-87.

Hanoune, R. 2000. "Représentations de construction et d'architecture sur la colonne Aurélienne." In $\mathrm{La} \mathrm{Col}$ onne Aurélienne: Autour de la colonne Aurélienne. Geste et image sur la colonne de Marc Aurèle à Rome, edited by J. Scheid and V. Huet, 205-10. Bibliothèque de l'École des Hautes Études, Section des Sciences Religieuses 108. Turnhout: Brepols.

Hanson, W.S., and I.P. Haynes, eds. 2004. Roman Dacia: The Making of a Provincial Society. JRA Suppl. 56. Portsmouth, R.I.: Journal of Roman Archaeology.

Hölscher, T. 1991a. "Einleitung." In "Narrative Systematik und politisches Konzept in den Reliefs der Traianssäule: Drei Fallstudien,” by L.E. Baumer, T. Hölscher, and L. Winkler, 261-66. JdI 106:261-95.

—. 1991b. "Vormarsch und Schlacht." In "Narrative Systematik und politisches Konzept in den Reliefs der Traianssäule: Drei Fallstudien,” by L.E. Baumer, T. Hölscher, and L. Winkler, 287-95. JdI 106:261-95.
2002. "Bilder der Macht und Herrschaft." In Traian: Ein Kaiser der Superlative am Beginn einer Umbruchzeit? edited by A. Nünnerick-Asmus, 127-44. Mainz: Philipp von Zabern.

Johnson, A. 1983. Roman Forts of the 1st and 2nd Centuries $A D$ in Britain and the German Provinces. New York: St. Martin's Press.

Koeppel, G. 1991. "Die historischen Reliefs der römischen Kaiserzeit VIII: Der Fries der Trajanssäule in Rom. Teil 1: Der Erse Dakische Krieg, Szenen I-LXXVIII." BJb 191:135-98.

1992. "Die historischen Reliefs der römischen Kaiserzeit VIII: Der Fries der Trajanssäule in Rom. Teil 2: Der Zweite Dakische Kreig, Szenen LXXIX-CLV.” B/b 192: 61-122.

Lander, J. 1984. Roman Stone Fortifications: Variation and Change from the First Century A.D. to the Fourth. BAR-IS 206. Oxford: British Archaeological Reports.

Lehmann, K. 1926. Die Trajanssäule: Ein römisches Kunstwerk zu Beginn der Spätantike. Berlin and Leipzig: Walter de Gruyter.

Lepper, F., and S. Frere. 1988. Trajan's Column: A New Edition of the Cichorius Plates. Introduction, Commentary, and Notes. Gloucester, England, and Wolfboro, N.H.: Alan Sutton Publishing.

Lusnia, S.S. 2006. "Battle Imagery and Politics on the Severan Arch on the Roman Forum." In Representations of War in Ancient Rome, edited by S. Dillon and K. Welch, 272-99. Cambridge: Cambridge University Press.

MacDonald, W.L. 1986. The Architecture of the Roman Empire. Vol. 2, An Urban Appraisal. New Haven and London: Yale University Press.

Maier, J. 1985. Architektur im römischen Relief. Bonn: Rudolf Habelt.

McCarthy, M.R. 1986. "Woodland and Roman Forts." Britannia 17:339-43.

Oltean, I. 2007. Dacia: Landscape, Colonisation, and Romanisation. New York: Routledge.

Oltean, I., and W.S. Hanson. 2001. "Military Vici in Roman Dacia: An Aerial Perspective." Acta Musei Napocensis 38(1):123-34.

Packer, J. 1997. The Forum of Trajan in Rome: A Study of the Monuments. Berkeley: University of California Press.

2008. "The Column of Trajan: The Topographical and Cultural Contexts." Review of La Colonne Trajane et les Forum Imperiaux, by M. Galinier. JRA 21:471-78.

Picard, G. 1962. "Les reliefs de l'arc de Septime Sévère au Forum romain." CRAI:7-14.

Pirson, F. 1996. "Style and Message on the Column of Marcus Aurelius.” PBSR 64:139-79.

Quante-Schöttler, D. 2002. Ante aedes: Darstellung von Architektur in römischen Reliefs. Hamburg: Verlag Dr. Kovač.

Rakob, F. 2000. "The Making of Augustan Carthage." In Romanization and the City: Creation, Transformations, and Failures. Proceedings of a Conference Held at the American Academy in Rome to Celebrate the 50 th Anniversary of the Excavations at Cosa, 14-16 May, 1998, edited by E. Fentress, 73-82. JRA Suppl. 38. Portsmouth, R.I.: Journal of Roman Archaeology.

Richmond, I. 1982. Trajan's Army on Trajan's Column. London: The British School at Rome.

Rockwell, P. 1985. "Preliminary Study of the Carving Techniques on the Column of Trajan." In Marmi antichi: Problemi d'impiego, di restauro e d'identificazione, edited by $\mathrm{P}$. 
Pensabene, 101-11. Studi Miscellanei 26. Rome: L'Erma di Bretschneider.

Rossi, L. 1971. "Dacian Fortifications on Trajan's Column.” AntJ51:30-5.

Roth, J. 2006. "Siege Narrative in Livy: Representation and Reality." In Representations of War in Ancient Rome, edited by S. Dillon and K. Welch, 49-67. Cambridge: Cambridge University Press.

Settis, S. 1988. "La Colonna: Strategie di Composizione, Strategie di Lettura." In La Colonna Traiana, edited by S. Settis, 86-255. Turin: Giulio Einaudi.

2005. "La Colonna Traiana: L'imperatore e il suo publico." In Giomate filologiche "Francesco Della Corte" IV, edited by F. Bertini, 65-86. Genoa: Dipartimento di Archeologia, Filologia Classica e loro Tradizioni.

Stefan, A.S. 2005. Les guerres daciques de Domitien et de Trajan: Architecture militaire, topographie, images et histoire. Rome: École Française de Rome.
Turcan-Déléani, M. 1958. "Les monuments représentés sur la Colonne Trajane:Schématisme et réalisme.” MÉFRA70: 149-76.

Wilkes, J.J. 2005. “The Roman Danube: An Archaeological Survey." JRS 95:124-225.

Williams, D. 1998. Romans and Barbarians: Four Views from the Empire's Edge, 1st Century AD. London: Constable.

Wilson Jones, M. 2000. Principles of Roman Architecture. New Haven: Yale University Press.

Zanker, P. 2000a. Introduction to The Column of Trajan, by F. Coarelli, vii-viii. Rome: Editore Colombo.

2000b. "Die Frauen und Kinder der Barbaren auf der Markussäule." In La Colonne Aurélienne: Autour de la colonne Aurélienne. Geste et image sur la colonne de Marc Aurèle à Rome, edited by J. Scheid and V. Huet, 163-74. Bibliothèque de l'École des Hautes Études, Section des Sciences Religieuses 108. Turnhout: Brepols. 